\title{
Return on Investment in Mining Companies: Intellectual Capital Aspect
}

\author{
Rita Martini ${ }^{1)^{*}}$, Sulaiman ${ }^{22}$, Maria $^{3)}$, Kartika Rachma Sari ${ }^{4)}$, \\ Lambok Vera Riama Pangaribuann", Hanina Sari ${ }^{6)}$ \\ 1), 2), 3), 4), 5), 6) Politeknik Negeri Sriwijaya, Palembang, Indonesia \\ *E-mail: martinirita65@gmail.com
}

\begin{abstract}
This research to know the relationship between intellectual capital and financial performance as measured by return on investment (ROI) using financial statement data for the period 2012-2016 from mining companies listed in the Indonesia Stock Exchange (IDX). The measurement model Intellectual Capital use Pulic's model with Value Added Intellectual Coefficient, which are a component of Value Added Capital Employed (VACA), Value Added Human Capital (VAHU) and Structural Capital Value Added (STVA). The analysis used was multiple linear regression. The results of the hypothesis test showed that VACA, VAHU and STVA together significantly effect to ROI. The results showed, STVA and VACA significant effect to ROI, while variable VAHU no significant impact to ROI because it being economic downturn that led to the mining business become lethargic. Further research can add a number of samples or a longer period because the result of this research is limited only 6 mining companies into the samples, so that future studies can provide a more perfect. Suggested to reexamine variables during stable economic condition to prove the possibility result which different with this research.
\end{abstract}

Keywords: return on investment, intellectual capital

\section{Introduction}

The mining sector is one of the main sector move the wheel of the Indonesian economy. The mining industry is also one of Indonesia's largest energy sources, $22 \%$. This energy source is used for electricity needs of Indonesia. And most of the output (77\%) of coal is exported out. This is a considerable portion of the country's revenue. On a national scale, mining activities are a dominant source of local revenue in some parts of Indonesia (https://www.kompasiana.com).

The problems faced by mining company is must be really careful in take into account the cost of energy as the costs energy is part of expenditure of the operational is increasing, of the total needs of company, the cost of energy at $40 \%$. Added on the cost of diesel fuel to the location mining, and problems the availability of and reliability of electricity, provision of electric power and the utilization of renewable energy can be solution chosen by mining company. Renewable energy source that can be used among others hydroelectric power station, the wind, and solar. "Renewable energy able to equip power plants powerful with 
diesel for mining in Indonesia, that uses a non-subsidy fuel and be a source of enormous. Burden the cost is very significant in remote areas that is not available electricity" (Jim Schnieders in www.tambang.co.id).

Minister energy and mineral resources suggest that mining company develop power plant earth heat or renewable energy their own, that we can be in control about the cost of when the market are many changes the demands (www.tambang.co.id). The utilization of renewable energy in industry mine will be developed and optimized, but needed capital cost a great to build its instalation, hence needed investors. Investment this can create the cost savings on the overall in the long term. "Many investors who had been interested in invest in the field of renewable energy and energy conservation. Now how speed up technology transfer to renewable energy included working with some countries such as Denmark, Norway, Austria and America. Forward Indonesia can be moved to partners not consumers technology by buying technology and build its industry here" (Minister Energy and Mineral Resources in www.esdm.go.id).

One way to achieve superiority in competition was to exercise a knowledge based business company to continue to hold. The approach that was used in judgment and measurement of intangible assets is IC that has become attention focus in various fields good technology information, management, and accounting. This creates a challenge for the accountant to identify, measuring and expressing it in a financial filing.

A measure to assess the efficiency of added value as a result of intellectual ability of a firm (Value Added Intellectual Coefficient-VAIC) (Pulic, 1999). A major component VAIC can be seen from resources company, namely Capital Employed Efficiency (CEE) measured by value Added Capital Employed (VACA), Human Capital Efficiency (HCE) measured by Value Added Human Capital (VAHU), and Structural Capital Efficiency (SCE) measured by Structural Capital Value Added (STVA).

In Indonesia, phenomena Intellectual Capital (IC) growing after the Statement of Financial Accounting Standard (SFAS) 19 (revised 2010) about the assets intangible. An intangible asset is assets non monetary cannot be identified without a physical and held for used in yield or surrender goods or services, leased to other parties, or the purpose of administration (Ikatan Akuntan Indonesia, 2010).

This study investigated the relationship between IC developed by Pulic and its effect on Return On Investment (ROI) using data from mining companies listed in the Indonesian Stock Exchange (IDX), researchers using financial statement data.

\section{Research Method \\ Intellectual Capital (IC)}

Stewart in Ulum (2009) defined IC as "the sum of everything in your every company knows that gives you a competitive advantage in the market place. Klein and Prusak in Ulum (2009) provide a preliminary definition of IC. Based on the above information, IC is a material composed, captured and used to generate a higher asset value. In general they agree and conclude that the IC captured and used to develop the company and has a value compared to other companies.

Pulic tried to develop a model of IC measurement that reflects the firm's ability to use physical capital efficiently, intellectual skills of human resources, and structural capital that describe the infrastructure capabilities and relationship of firm (Pulic, 1999). This coefficien as Value Added Intellectual Coefficient (VAIC) that describe the firm's intellectual capability. Kammath (2008) in Sawarjuwono \& Kadir (2003) VAIC is summation of Value Added of 
Capital Employed (VACA), Human Capital Value Added (VAHU) and Structural Capital Value Added (STVA).

The theoretical framework of this study is premised upon the Pulic Model. Stages of IC calculation using the model VAIC (Pulic, 1999) is following:

1. Calculate the Value Added (VA). VA = OUT - IN. OUT $=$ Output: total sales and other revenue; $\mathrm{IN}=$ Input: sales expenses and other costs (not including personnel expenses). VA also can be calculated as follows: $\mathrm{VA}=\mathrm{OP}+\mathrm{EC}+\mathrm{D}+\mathrm{A}$. $\mathrm{OP}=$ Operating profit; $\mathrm{EC}=$ Employee costs (personnel expenses); $\mathrm{D}=$ Depreciation; $\mathrm{A}=$ amortization.

2. Calculate the VACA. VACA is a measure of VA produced by a unit of physical capital. The resulting contribution ratio of each unit CE for the VA. VACA = VA / CE. $\mathrm{VACA}=$ the ratio of the VA to the $\mathrm{CE} ; \mathrm{CE}=$ Capital employed; available funds (derived from net income, and equity).

3. Calculate the VAHU. This ratio is an indicator of the value added generated from each dollar invested in HC. This ratio shows the contribution made by each dollar invested in HC against VA organization. VAHU $=\mathrm{VA} / \mathrm{HC}$. VAHU $=$ The ratio of VA to HC. VA = Value Added; HU = Human Capital: personnel expenses.

4. Calculate STVA. Ratio indicates the number of SC that companies use to obtain one dollar of VA. STVA = SC / VA. STVA = The ratio of the SC to the VA; SC = Structural Capital: VA reduced HC.

5. Calculate VAIC. VAIC identify an organization's intellectual abilities which can be regarded as a BPI (Business Performance Indicators). VAIC is the sum of the previous three components, namely: VACA, VAHU and STVA. VAIC = VACA + VAHU + STVA.

\section{Return on Investment (ROI)}

The ratio which the count of the level of repayment investment in assets in obtaining profit or advantage. The formula in counting ROI is:

$$
\text { ROI }=\text { Profit After Expense and Tax } \times 100 \%
$$

\section{Population and Sample}

Total Assets

The population and sample in this research was the coal mining company sector listed on the IDX in the period 2012-2016. The number of coal mining company sector were 23 companies that the size of the population in this research. The determination of sample technique in this research use of purposive sampling.

The criteria used to sample selection is a company coal mining sector registered at the IDX, in audited financial report as well as having equity value and a positive profit. Based on above criteria, there were six companies that meet the criteria.

\section{Data Analysis Technique}

Once the data is collected, then analyzed the data. Data processing and data analysis in this study uses multiple regression model. The independent variable in this research is $\operatorname{VACA}\left(\mathrm{X}_{1}\right)$, VAHU $\left(\mathrm{X}_{2}\right)$ and STVA $\left(\mathrm{X}_{3}\right)$, while independent variable is ROI $(\mathrm{Y})$.

\section{Result and Discussion}

Multiple regression analysis used to know the effect of IC to ROI. Based on the calculation on obtained the results of data processing showing constant value and the regression coefficient (table 1).

Based on the test result that showing by the table 1, the form of the regression equation is: 


$$
\mathrm{Y}=0.036+0.502 \mathrm{X}_{1}+0.640 \mathrm{X}_{2}-0.128 \mathrm{X}_{3}+\mathrm{e}
$$

Test the coefficient of determination is used to know correlation values between IC to ROI. The output of the test were processed using SPSS (table 2).

Coefficients ${ }^{\mathrm{a}}$

Table 1 Multiple Regression Testing

\begin{tabular}{lllllll}
\hline Model & \multicolumn{2}{l}{ Unstandardized Coefficients } & \multicolumn{2}{l}{ Standardized Coefficients } & \multirow{2}{*}{ T } & \multirow{2}{*}{ Sig. } \\
\cline { 1 - 4 } & $\mathrm{B}$ & Std. Error & Beta & & \\
\hline (Constant) & .036 & .087 & & .420 & .678 \\
VACA & .235 & .050 & .502 & 4.704 & .000 \\
VAHU & .022 & .007 & .640 & 3.211 & .004 \\
STA & -.102 & .154 & -.128 & -.666 & .511 \\
\hline
\end{tabular}

a. Dependent Variable: ROI

Source: Output of SPSS Version 20. (2017)

Table 2 Coefficient of Determinantion Test

Model Summary ${ }^{\mathrm{b}}$

\begin{tabular}{llllll}
\hline $\begin{array}{l}\text { Mod } \\
\mathrm{el}\end{array}$ & $\mathrm{R}$ & $\mathrm{R}$ Square & $\begin{array}{l}\text { Adjusted } \\
\text { Square }\end{array}$ & $\mathrm{R}$ & Std. Error of the Estimate \\
\hline 1 & $.867^{\mathrm{a}}$ & .751 & .722 & .05389 \\
\hline
\end{tabular}

a. Predictors: (Constant), SRVA, VACA, VAHU

b. Dependent Variable: ROI

Source: Output of SPSS Version 20. (2017)

Table 2 shows the coefficient of determination (Adjusted $\mathrm{R}^{2}$ ) is 0.7220 or $72.20 \%$. It means the combination of VACA, VAHU, and STVA can explain ROI was $72.20 \%$, while the remaining $27.80 \%$ explained by other variables outside of this research.

\section{The Effect of VACA to ROI}

VACA having sig-t of 0,000 and $\alpha=0.05$ so, sig-t $<\alpha$ and having tcount of 4.704 with table 1.705. So, tcount $>$ table, then $\mathrm{H}_{a}$ accepted. It means there are significant positive impact between VACA against ROI. This result consistent with Widarwati (2008) of those who deduce variabel VACA it has positive effects and significantly to profitability. VACA against profitability measured using ROI denoting the mining companies funding available as equity and on its net income in improving the added value which eventually improve the company profitability.

\section{The Effect of VAHU to ROI}

Variabel VAHU having sig-t of 0.002 dan $\alpha=0.05$ so, sig- $t<\alpha$ and having tcount of 3.211 with table 1.705 . So, tcount $>$ table, $\mathrm{H}_{\mathrm{a}}$ accepted. Means VAHU have positive and significant impact on ROI. The result of this research consistent with research stated variable VAHU have had a positive impact and significant to profitability (Ulfa, 2014). The influence of VAHU to ROI show knowledge and skills owned employees have to exert an influence upon profitability, as the motivation to innovate them and processes improve business to be more efficient that eventually can be increase profitability company.

\section{The Effect of STVA to ROI}

Based on the calculation, known variable STVA having sig-t of 0.2555 and $\alpha=0.05$. So, sig- $t>\alpha=0.05$ and having $t_{\text {count }}$ of -0.666 with table 1.705 . So, $t_{\text {count }}<t_{\text {table, }}$ then $\mathrm{H}_{\mathrm{o}}$ accepted. It means STVA has proven to be not have had a positive impact that significant to ROI. This 
result consistent with research (Ulfa, 2014 and Widarwati, 2008) found that STVA not have had a positive impact and significantly to profitability. No impact of STVA to ROI denoting the mining companies have not been able to in fulfilling the process routine and its structure that supports business employees to produce performance intellectual optimal and performance business as a whole. With not far error company transformed knowledge or intellectual employees into a supporting structure of employee performance, the company have not been able to develop structure capital that produces excellence compete relatively small can increase (Artinah \& Ahmad, 2011).

The Effect of VACA, VAHU and STVA to ROI

Based on the calculation on variable VACA, VAHU and STVA simultaneously having sig-t of 0.000 and $\alpha=0.05$. So, sig- $t<\alpha 0.05$ and $F_{\text {count }}$ of 26.13 and $F_{\text {table }}$ with 2.98, so $F_{\text {count }}>$ $\mathrm{F}_{\text {table. }} \mathrm{H}_{\mathrm{a}}$ accepted, it means VACA, VAHU, and STVA simultaneously have had positive impact that significant to ROI.

The result of this research consistent with (Nuryaman, 2015), stated that IC has a positive impact on profitability. The influence VACA, VAHU and STVA to profitability measured by ROI showed that the mining company have used equity and net profit, knowledge and skill employees to innovate and have lived up the process routine companies and structure that supports business employees to improve their IC performance.

\section{Conclusion and Suggestion Conclusion}

Based on the problems and discussion about Return on Investment in Mining Companies: Intellectual Capital Aspect, it can be concluded as follows:

1. The study has been able to establish the VACA, VAHU and STVA proven simultaneously have had a positive impact that significant to ROI in the mining companies. The $72.20 \%$ variable ROI can be explained by VACA, VAHU and STVA, the rest $27.80 \%$ described by the other factors that are not pursuing in this research. VAHU the most dominant influence ROI.

2. VACA proven have had a positive and significant impact on return on investment. This indicates the mining companies have rely on their funds are as equity and its net profit increase the value added who had increased profitability company.

3. VAHU proven have had a positive and significant impact on ROI. This indicates the mining companies have used knowledge and skill owned employees as the motivation to innovate them and processes improve business to be more efficiency that eventually can be increase profitability company.

4. STVA has negative that significant impact on ROI. This indicates the mining companies have not been able to in fulfilling the process routine companies and its structure that supports business employees to produce performance intellectual optimal and performance business as a whole.

\section{Suggestion}

The study, recommends that limited the result of this research allow the presence of different results if added that the number of sample or a period more long. In addition suggested to reexamine variables on the coal mining companies when conditions economic stable to prove the possibility that different results with this research.

\section{Acknowledgement}


This research is based on work supported by Politeknik Negeri Sriwijaya, Indonesia. The author thankfully acknowledges really scientific discussion with our colleagues from Politeknik Negeri Sriwijaya, Indonesia.

\section{References}

Artinah, Budi \& Ahmad Muslih. (2011). Pengaruh intellectual capital terhadap capital gain. Journal Spread, 1(1).

Bontis, N. W.C.C. Keow, S. Richardson. (2000). Intellectual capital and business performance in Malaysian industries. Journal of Intellectual Capital, 1(1), 85-100.

(2001). Assessing knowledge assets: a review of the models used to measure intellectual capital. International Journal of Technology Management, 3(1), 41-60.

Clarke, Martin et al. (2010). Intellectual capital and firm performance in Australia. Departement of Accountancy and Business Law. Working Paper Series No.12.

Indonesia Stock Exchange (IDX). (2016). Annual financial statements and annual report. www.idx.co.id.

Ikatan Akuntansi Indonesia. (2010). Pernyataan standar akuntansi keuangan no 19 tentang aset tak berwujud. Jakarta: Salemba Empat.

Irawati, Susan. (2006). Financial management. Bandung: Pustaka.

Kamath, Bharathi, G. (2008). Intellectual capital and corporate performance in Indian Pharmaceutical Industry. Journal of Intellectual Capital, 9 (4), 684

Nuryaman. (2015). The influence of intellectual capital on the firm's value with the financial performance as intervening variable. $2^{\text {nd }}$ Global Conference on Business and Social Science-2015, Bali, Indonesia. Available online at www.sciencedirect.com

Ozkan, Nasif, Sinan Cakan \& Murad Kayacan. (2016). Intellectual capital and financial performance: A study of the Turkish Banking Sector.

Pulic, A. (1999). Basic information on VAIC. www.vaic-on.net.

Renewable energy. www.tambang.co.id.

Renewable energy. www.esdm.go.id.

Sawarjuwono, T. \& Kadir. (2003). Intellectual capital: perlakuan, pengukuran, dan pelaporan (sebuah library research). Jurnal Akuntansi dan Keuangan, 5(1), 35-37.

Tambang, Ekonomi, dan Lingkungan. https://www.kompasiana.com/atq2r1/tambangekonomi-dan-lingkungan 56a14b57bc22bd0314e4d471.

Ulfa, Maricha. (2014). Pengaruh intellectual capital terhadap profitabilitas, produktivitas dan pertumbuhan perusahaan Perbankan. Jurnal Ekonomi dan Bisnis Islam, IX (1).

Ulum, Ihyaul. (2009). Intellectual capital: konsep dan kajian empiris. Yogyakarta: Graha Ilmu

Widarwati, Estu \& Wila Susilawati. (2008). Pengaruh intellectual capital terhadap return on investment. Dimensia, 2(2). 